\title{
Continuous Set Data Type
}

National Cancer Institute

\section{Source}

National Cancer Institute. Continuous Set Data Type. NCI Thesaurus. Code C95638.

A data type comprised of a set of unordered, quantitative values. 